\title{
Analysis of Implementation Factors of Safety and Health Program on Work Accident in CV. Pasific Harvest Muncar District Banyuwangi
}

Tri Suryo Wibowo

Magister of Public Health Program of Stikes Surya Mitra Husada Kediri

Email:

trisuryowibowo22@gmail.com

Received: March 12, 2019

Accepted : April 13, 2019

Published : May 10, 2019
ABSTRACT

Human Resources (HR) occupies a strategic and important place among other resources. In this case the company needs to pay attention to the security of employees while working in the company. One form of protection is to provide Occupational Safety and Health (K3) employees. The purpose of this study was to analyze the most dominant factors affecting work accidents in CV. Pacific Harvest Muncar Banyuwangi. The research design used was cross sectional. The research population is All employees in the production department CV. Pacific Harvest of 273 people and a large sample of 162 people. The sampling technique using Simple random sampling and data collection using questionnaires and then analyzed using multiple linear regression. The results showed that between attitudes to work accidents no significant effect with significant value $=0.001<0.05$ ). Between knowledge of accidents of work there is significant influence with significant value $=0,000<0.05$ and there is a behavioral effect on work accidents with significant value $=0.025<0.05$. Based on the research, it is necessary to make the knowledge about K3 more enhanced to form a safe attitude and behavior in working and obeying all regulations and SOP K3 applied by the company.

Keywords: Occupational safety and health program, knowledge, attitude, behavior

This is an open-acces article distributed under the terms of the Creative Commons Attribution-ShareAlike 4.0 International License.

\section{INTRODUCTION}

Competition of an increasingly competitive industry requires companies more optimize all resources it has, the outline of its resources. : Financial, physical, human, technological. Resources owned by a limited number of companies, the company is required to empower and optimize to achieve corporate goals. Companies engaged in the industry more often use heavy equipment or technology in the production process. This causes the level of work accidents in companies engaged in higher industry. Along with the increase of work accidents that occur in a company will increase also employees who are absent from his work.

According Sutedi (2009), Occupational Safety and Health (K3) is a program created for the workers/laborers and employers for prevention for the incidence of occupational accidents and diseases caused by working relationships within the work environment by identifying things that are potentially cause workplace accidents and illnesses resulting from employment, and anticipatory action in the event of such a case. Occupational Safety and Health $(\mathrm{OSH})$ is one of the important aspects that a company needs to implement because $\mathrm{K} 3$ is a right for every employee.

Based on data from the International Labor Organization (ILO) in 2013, 1 worker in the world dies every 15 seconds due to workplace accidents and 160 workers suffering from work-related illness. The previous year (2012) the ILO recorded the death toll due to accidents and occupational diseases (PAK) of 2 
million cases each year (MOH, 2014). The Ministry of Manpower (Kemnaker) claims the case of accidents during 2017 has decreased compared to 2016. In 2017, the number of occupational accidents recorded as many as 80,393 cases, down about 20,975 cases (Republika, 2017). According to Setiajit the head of East Java's Disnakertrans said that East Java emergency work accident because in a year in 2017, there were 14,552 accidents in the company area. While accidents outside the company area reached 1,755 cases (Detiknews, 2017).

Implementation of safety and health management system that has been implemented properly by the company and all its employees, it will create a good working environment. Work accidents that occur will be reduced. Conversely, if the company does not really implement the safety and health management system properly, and employees do not obey the rules and run well, then the work accident will increase. Workplace accidents can be caused by several factors including worker factors and unsafe working environment factors. Worker factors become more frequent factors causing work accidents. This is because workers often neglect matters relating to occupational safety and health in doing their work. Work accidents that occur will hamper the production process of the company. This should be prevented by implementing the Occupational Safety and Health (K3) program in the company. K3 program is run so that accidents in the company work can be reduced. Accidents arise as a result of the management of potential hazards and risks to low occupational safety and health. Potential hazards and risks can be sourced from tools and materials, machines used, work processes, unsafe working environment, worker constraints, low employee safety behavior, ergonomic working conditions, job organizing and non-conducive working culture (Kurniawidjaja, 2011). Based on the above description of the researcher interested in taking the title Analysis of the factors of implementation of occupational safety and health programs against the occurrence of work accidents in the CV. Pacific Harvest Banyuwangi.

\section{MATERIALS AND METHODS}

The design used in this study is cross-sectional. The population is All employees in the production CV. Pacific Harvest Muncar Banyuwangi Regency as many as 273 people. The sample size is 162 respondents using simple random sampling technique. Independent research variables are attitude, knowledge and behavior. Dependent variable is work accident. Data were collected using questionnaire, then the data were analyzed using multiple linear regression test with level of significance $\alpha \leq 0,05$.

\section{RESULTS}

Table 1. Frequency Distribution Based on Attitude in CV. Pacific Harvest Muncar Banyuwangi District From 26 - 31 March 2018

\begin{tabular}{ccc}
\hline Attitude & $\mathrm{n}$ & $\mathrm{f}(\%)$ \\
\hline Good & 149 & 92,0 \\
\hline Enough & 13 & 8,0 \\
\hline Less & - & - \\
\hline Total & 162 & 100 \\
\hline
\end{tabular}

Source: Primary data of research in 2018

Based on table 1 shows that of 162 respondents most attitudes of good category employees are as many as 149 respondents $(92.0 \%)$. 
Table 2. Frequency Distribution Based on Knowledge at CV. Pacific Harvest Muncar Banyuwangi District From 26 - 31 March 2018

\begin{tabular}{ccc}
\hline Knowledge & $\mathrm{n}$ & $\mathrm{f}(\%)$ \\
\hline Good & 148 & 91,4 \\
\hline Enough & 14 & 8,6 \\
\hline Less & - & - \\
\hline Total & 162 & 100 \\
\hline
\end{tabular}

Source: Primary data of research in 2018

Based on table 2 shows that of 162 respondents most of the knowledge of good category employees are as many as 148 respondents $(91.4 \%)$.

Table 3. Frequency distribution based on Behavior in CV. Pacific Harvest Muncar Banyuwangi District From 26 - 31 March 2018

\begin{tabular}{ccc}
\hline Behavior & $\mathrm{n}$ & $\mathrm{f}(\%)$ \\
\hline Good & 149 & 92,0 \\
\hline Enough & 13 & 8,0 \\
\hline Less & - & - \\
\hline Total & 162 & 100 \\
\hline
\end{tabular}

Source: Primary data of research in 2018

Based on table 3 shows that of 162 respondents most of the good category employee behavior as many as 146 respondents $(92.0 \%)$.

Table 4 . Frequency distribution by accident in CV. Pacific Harvest Muncar Banyuwangi District From 26 31 March 2018

\begin{tabular}{ccc}
\hline Accident & $\mathrm{n}$ & $\mathrm{f}(\%)$ \\
\hline Never & 150 & 92,6 \\
\hline Ever & 12 & 7,4 \\
\hline Total & 162 & 100 \\
\hline
\end{tabular}

Source: Primary data of research in 2018

Based on table 4 shows that of 162 respondents most never had an accident that is as much as 150 respondents $(92.6 \%)$.

Table 5 Regression Test Results

\section{Coefficients $^{\mathrm{a}}$}

\begin{tabular}{|c|c|c|c|c|c|c|}
\hline & \multirow{2}{*}{ Model } & \multicolumn{2}{|c|}{ Unstandardized Coefficients } & \multirow{2}{*}{$\frac{\text { Standardized Coefficients }}{\text { Beta }}$} & \multirow{2}{*}{$\mathrm{t}$} & \multirow{2}{*}{ Sig. } \\
\hline & & $\mathrm{B}$ & Std. Error & & & \\
\hline & (Constant) &,- 704 &, 090 & & $-7,783$ &, 000 \\
\hline \multirow{3}{*}{1} & Attitude & ,237 & ,070 & ,245 & 3,384 & ,001 \\
\hline & Knowledge & ,330 & ,067 & ,354 & 4,918 & ,000 \\
\hline & Behavior &, 152 & 068 & 158 & 2,257 & 025 \\
\hline
\end{tabular}

a. Dependent Variable: Accident

The dependent variable in multiple linear regression model are the occupational accidents ( $\mathrm{Y}$ ) while the independent variable is the attitude variable $\left(\mathrm{X}_{1}\right)$, knowledge $\left(\mathrm{X}_{2}\right)$ and behavior $\left(\mathrm{X}_{3}\right)$. 
Regression model based on the results of the above analysis is :

$\hat{Y}=-0,704+0,236\left(X_{1}\right)+0,330\left(X_{2}\right)+0,152\left(X_{3}\right)$

The interpretation of the above equation is:

$\beta_{0}=-0.704, \mathrm{~d}$ natural model -0.704 is the intersection point between the regression line with the $\mathrm{Y}$ axis (intercept).

$\beta_{1}=0,236$, regression coefficient for attitude variable $\left(X_{1}\right)$ is positive value equal to 0,236 means that height of attitude hence lower work accident $(\mathrm{Y})$ or vice versa.

$\beta_{2}=0.330$, the regression coefficient for the knowledge variable $\left(\mathrm{X}_{2}\right)$ is positive value of 0.330 means that the higher the knowledge then semin low the work accidents $(\mathrm{Y})$ or vice versa.

$\beta_{3}=0,152$, regression coefficient for work behavior variable $\left(X_{3}\right)$ is positive value equal to 0,152 meaning that the higher the work behavior the lower the work accident $(\mathrm{Y})$ or vice versa.

Table 6. Test F Results

ANOVA $^{\mathrm{a}}$

\begin{tabular}{|c|c|c|c|c|c|c|}
\hline & Model & Sum of Squares & $\mathrm{df}$ & Mean Square & $\mathrm{F}$ & Sig. \\
\hline \multirow{3}{*}{1} & Regression & 3,773 & 3 & 1,258 & 27,078 &, $000^{\mathrm{b}}$ \\
\hline & Residual & 7,338 & 158 & ,046 & & \\
\hline & Total & 11,111 & 161 & & & \\
\hline
\end{tabular}

a. Dependent Variable: Accident

b. Predictors: (Constant), Behavior, Attitude, Knowledge

Based on the results of statistical decision, if the significance $\square \alpha(0.000<0.05)$, then Ho is rejected it means an attitude $\left(\mathrm{X}_{1}\right)$, knowledge $\left(\mathrm{X}_{2}\right)$, and behavior $\left(\mathrm{X}_{3}\right)$, simultaneously significant influence on occupational accidents (Y).

Table 7. Test t Results

Coefficients $^{\mathrm{a}}$

\begin{tabular}{|c|c|c|c|c|c|c|}
\hline & \multirow[t]{2}{*}{ Model } & \multicolumn{2}{|c|}{ Unstandardized Coefficients } & \multirow{2}{*}{$\begin{array}{l}\text { Standardized } \\
\text { Coefficients } \\
\text { Beta } \\
\end{array}$} & \multirow[t]{2}{*}{$\mathrm{t}$} & \multirow[t]{2}{*}{ Sig. } \\
\hline & & B & Std. Error & & & \\
\hline \multirow{4}{*}{1} & (Constant) &,- 704 &, 090 & & $-7,783$ &, 000 \\
\hline & Attitude & 237 &, 070 & ,245 & 3,384 &, 001 \\
\hline & Knowledge & 330 &, 067 &, 354 & 4,918 &, 000 \\
\hline & Behavior &, 152 & ,068 & 158 & 2,257 &, 025 \\
\hline
\end{tabular}

a. Dependent Variable: Accident

For attitudinal variables $\left(\mathrm{X}_{1}\right)$ significant value $0.001<0.05$, thus Ho is rejected, the attitude $\left(\mathrm{X}_{1}\right)$ partial effect on the accident in the CV. Pacific Harvest Muncar Banyuwangi.

For knowledge variable $\left(\mathrm{X}_{2}\right)$ significant value $0,000<0,05$, thus Ho is rejected then knowledge $\left(\mathrm{X}_{2}\right)$ partially effect on work accident at CV. Pacific Harvest Muncar Banyuwangi.

For behavioral variables $\left(\mathrm{X}_{3}\right)$ significant value $0.025<0.05$, thus Ho is rejected, the behavior $\left(\mathrm{X}_{3}\right)$ partially affect the work accident at CV. Pacific Harvest Muncar Banyuwangi. 


\section{DISCUSSION}

\section{A. Attitudinal factors that affect work accidents}

Based on the results of this study showed that of 162 respondents most of the employee attitude good and never had an accident as many as 143 respondents (84.9\%), and t test results for attitude variable $\left(\mathrm{X}_{1}\right)$ significant value $0.001<0.05$, thus Ho is rejected then attitude $\left(\mathrm{X}_{1}\right)$ partially affect the work accident in $\mathrm{CV}$. Pacific Harvest Muncar Banyuwangi.

The results of this study are similar to the results of previous research conducted by Kalalo (2016) who examines the relationship between knowledge and attitude about K3 with the incidence of work accidents in the employee group in Belang Village Belang District, Southeast Minahasa Regency. This research indicates that there is correlation between knowledge about K3 and the incidence of accidents in employee group $(\mathrm{p}=0,000)$, there is correlation between attitude about $\mathrm{K} 3$ with accident incident in employee group $(\mathrm{p}=0,002)$. There is a relation between knowledge and attitude about K3 with accident incident on employee group.

According to Myers (2014) attitude is a pleasant or unpleasant evaluative reaction to something or someone who is often rooted in one's beliefs and arises in one's feelings and behaviors. Attitude is a reaction or a person's response to a stimulus or object. Attitudes in everyday life are emotional reactions to social stimulus (Notoatmodjo, 2012).

Components of attitude according to Rahayuningsih (2010) includes three things: cognitive components associated with belief (beliefs and beliefs), ideas, and concepts. Part of the cognitive: perception, stereotype, opinion of the individual about something; the affection component is related to one's emotional life, concerning the individual's feelings toward the attitude object and the emotional problem. Affection is a component of pleasure or displeasure in an object, and a behavioral / conative component is a component associated with a person's tendency to behave toward an attitude object.

Occupational health and safety is a safeguard aimed at labor and other people in the workplace or company is always safe and sound, and that every production is used safely and efficiently. The running of the company's health and safety program depends on the positive attitude of the employees. Therefore, the formation of attitudes can be influenced by personal experience, the influence of others who are considered important, the influence of culture, and the media information.

Positive attitudes of employees who are willing to accept and implement all procedures and regulations of health and safety are created and shaped by companies such as using personal protective equipment and so can minimize and prevent work accidents. Positive attitude can lead to positive behavior so as to avoid minor accidents and even more severe accidents. Conversely workers who have a negative attitude will tend to not care about the environment and the dangers around it so that employees are vulnerable to work accidents.

\section{B. Knowledge factors that affect work accidents}

Based on the results of this study shows that from 162 respondents most of the employee knowledge is good and never had accidents as many as 143 respondents $(88.3 \%)$, and the result of $t$ test for knowledge variable $\left(\mathrm{X}_{2}\right)$ significant value $0,000<0.05$, with so Ho is rejected then knowledge $\left(\mathrm{X}_{2}\right)$ partially affect the work accident in CV. Pacific Harvest Muncar Banyuwangi.

The result of this research is similar to previous research done by Rifai (2017) which examines the relationship of knowledge and participation of occupational safety and health (K3) On the nurse with accident incident in Hospital X Yogyakarta. The results showed that there was a significant correlation between the knowledge of nurse in Occupational Safety and Health (K3) with the incidence of work accident ( $\mathrm{p}$ value $=0,003<0,05$ ), there was a significant correlation between the participation of nurse in Occupational Safety and Health with work accident ( $\mathrm{p}$ value $=0.011<0.05$ ).

Knowledge is the result of knowing and occurs after people make sense to a particular object. Knowledge can be obtained personally or intervention either directly or indirectly.

According to Budiman and Riyanto (2013) factors affecting knowledge include: a) Education is the process of changing the attitude and behavior of a person or group and is an effort to mature man through the efforts of teaching and training; b) information / mass media Information gained from formal and non-formal education can have a short-term effect resulting in change and increased knowledge; c) social, cultural and economic, Someone who has a good social culture then the knowledge will be good but if the social culture is not good then the knowledge will be less good; d) A good environment of knowledge gained will be good 
but if the environment is not good then the knowledge gained will also be less good; e) experience, experience can be gained from the experiences of others as well as oneself so that the experience gained can improve one's knowledge; f) age, The increasing age will be more developed also capture power and mindset so that knowledge will also get better and increase.

Workplace accidents can occur due to lack of staff knowledge about occupational health and safety. Employees with good knowledge will be able to distinguish or understand the dangers around it and can do the work in accordance with existing procedures because they are aware of the risks received if making mistakes or not using work equipment in accordance with the SOP in the company that is experiencing work accidents.

Well-informed employees will try to avoid minor accidents because they are aware that minor accidents will lead to more severe work accidents. If employees have good knowledge then they will act positively and try to avoid work accidents. Conversely, low-knowledge employees will tend to ignore the dangers around them and not do the work according to the procedure because ignorance of risk will be accepted and employees tend to work in a hurry and just want to finish the job quickly to save time and break time to be faster. Therefore, low labor inspection of occupational health and safety can lead to minor accidents and more severe accidents.

\section{Behavioral factors of use of PPE that affect work accidents}

Based on the results of this study showed that of the 162 respondents mostly good employee behavior and never had an accident as much as 142 respondents $(87.7 \%)$, and the results of the $t$ test for behavioral variables $\left(\mathrm{X}_{3}\right)$ significant value $0.025<0.05$, thus Ho is rejected then the behavior $\left(\mathrm{X}_{3}\right)$ partially affect the work accident in CV. Pacific Harvest Muncar Banyuwangi.

The results of this study are similar to the results of previous research conducted by Faris (2014) which examines the effect of labor behavior and work environment that moderated the factors of work experience and the level of education on construction accidents in Surabaya. Based on the results of employment behavior analysis significantly affect work accidents $(\mathrm{R}=0,519)$. While the working environment does not significantly affect work accidents $(R=0.003)$, and at the education level significantly affects work accidents, whereas before moderated $\mathrm{R}=0.616$ and after moderated $\mathrm{R}=0.642$.

Behavior is the result of all kinds of experience as well as human interaction with the environment that is manifested in the form of knowledge, attitude and action. Behavior is the response / reaction of an individual to the stimulus that comes from outside or from within himself (Notoatmojo, 2010). Behavior is a function of individual characteristics and environment. Individual characteristics include various variables such as motives, values, traits, personality, and attitudes that interact with each other and then interact also with environmental factors in determining behavior. Environmental factors have great power in determining behavior, even the power is greater than individual characteristics (Azwar, 2010).

Human behavior (human behavior) is a reaction that can be simple or complex. In humans in particular and in various animal species there are generally forms of instinctive behavior (species-specific behavior) which is based on nature to sustain life. Human behavior is the result of all kinds of experience as well as human interaction with the environment manifested in the form of knowledge, attitude, and action (Achmadi, 2013).

Human behavior plays an important role in causing an accident, so an effective way to prevent the occurrence of work accidents is to avoid the occurrence of unsafe behavior. Unsafe worker behavior is also the cause of workplace accidents, as there are workers who do not use personal protective equipment. Therefore, the occurrence of work accidents of course makes a big problem for the continuity of the company. Losses suffered not only in the form of material losses large enough but more than that is the incidence of casualties are not few in number.

The good of one's behavior in utilizing K3 equipment can be influenced by three factors, namely predisposing factor, manifested in knowledge, attitude, belief, perception, belief and values; enabling factors, manifested in the physical environment, available or unavailability of facilities or supporting facilities; the driving factor, manifested in action to gain support or encouragement. 


\section{CONCLUSION}

In this research can be concluded as follows:

There is influence attitude toward work accident at CV. Pacific Harvest Muncar Banyuwangi (significant value $=0.001<0.05$ ) .

There is influence of knowledge on work accident at CV. Pacific Harvest Muncar Banyuwangi (significant value $=0,000<0.05$ ).

There is influence of behavior toward work accident in CV. Pacific Harvest Muncar Banyuwangi ( significant value $=0.025<0.05$ ).

\section{SUGGESTION}

\section{For respondents}

Employees further improve knowledge about $\mathrm{K} 3$ in order to form attitudes and behaviors that are safe in work and comply with all regulations and SOP K3 applied by the company.

\section{For research sites}

Company management is more active in supervising employees especially in the production sector in implementing the OSH program.

3. For Further Researchers

Can develop this research by considering other factors that influence knowledge, attitude and behavior toward the occurrence of work accident.

\section{REFERENCES}

Achmadi, U., F. (2013). Kesehatan Masyarakat Teori dan Aplikasi. Jakarta: Rajawali Pres.

Azwar, \& Saifuddin. (2010). Metode Penelitian. Yogyakarta: Pustaka Pelajar.

Budiman, \& Riyanto, A. (2013). Kapita Selekta Kuisioner Pengetahuan dan Sikap. Dalam Penelitian Kesehatan. Jakarta: Salemba Medika.

Depkes RI. (2014). 1 Orang Pekerja Di Dunia Meninggal Setiap 15 Detik Karena Kecelakaan Kerja http://www.depkes. go.id/article/print/201411030005/.

Detiknews. (2017). 14.552 Kasus Kecelakaan Kerja Terjadi di Jatim Sepanjang 2017. https://news.detik.com/.

Faris, A., I. (2014). Pengaruh perilaku tenaga kerja dan lingkungan kerja yang dimoderasi faktor pengalaman kerja dan tingkat pendidikan terhadap kecelakaan kerja konstruksi di Surabaya. Jurnal. http://jurnal.itats.ac.id/wpcontent/uploads/ 2015/02/.

Kalalo, S., Y. (2016). Hubungan antara pengetahuan dan sikap tentang K3 dengan kejadian kecelakaan kerja pada kelompok karyawan di Desa Belang Kecamatan Belang Kabupaten Minahasa Tenggara. Jurnal Ilmiah Farmasi. https://ejournal. unsrat.ac.id/index.php/pharmacon/article/view/11254.

(K3) Pada perawat dengan kejadian kecelakaan kerja di Rumah Sakit X Yogyakarta. Jurnal Publikasi Kesehatan Masyarakat Indonesia. http://ppjp.unlam. ac.id/journal/index.php/JPKMI/article/view/4320.

Kurniawidjaja, M. (2011). Teori dan Aplikasi Kesehatan Kerja. Jakarta: UI-Press.

Rahayuningsih, S., U. (2010). Psikologi Umum 2. Jakarta: Gunadarma.

Rebuplika. (2017). Kemenaker Klaim Kasus Kecelakaan Kerja Tahun 2017 Menurun. http://nasional.republika.co.id/.

Rifai, M. (2017). Hubungan pengetahuan dan partisipasi keselamatan dan kesehatan kerja. 
Myers, \& David, G. (2014). Psikologi Sosial Jilid 2. Jakarta: Salemba Humanika.

Notoatmodjo, S. (2012). Promosi kesehatan dan Perilaku Kesehatan. Jakarta: Rineka Cipta.

Sutedi, A. (2009). Hukum Perburuhan, Jakarta: Sinar Grafika. 